\title{
Sanitary and physiological quality of 'purple' corn (Zea mays $L$ ) seeds submitted to thermotherapy
}

\author{
Qualidade sanitária e fisiológica de sementes de milho 'Roxo' (Zea mays L.) \\ submetidas à termoterapia
}

\author{
Hugo Vieira' (D), João Victor da Silva Martins² (D), Gabriel Ginane Barreto² (D), \\ Rommel dos Santos Siqueira Gomes ${ }^{2 *}$ (D), Edcarlos Camilo Silva² ${ }^{(D)}$, Luciana Cordeiro Nascimento²
}

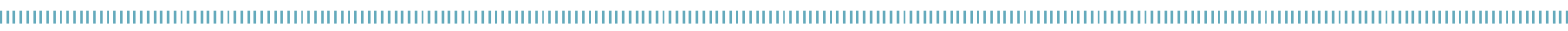

\begin{abstract}
The use of seeds with good sanitary and physiological potential ensures the establishment of the crop, with a uniform, vigorous and disease-free seedling stand, which will result in good productivity levels. Seen that, the objective was to evaluate the sanitary and physiological quality of purple corn seeds (Zea mays L.) submitted to thermotherapy. They were subjected to heat treatment with immersion in sterile distilled water (SDW) heated at 50,60 and $70{ }^{\circ} \mathrm{C}$ for 1,2 , and 3 minutes. The control $(0 \mathrm{~min})$ correspondens only to immersing the seeds in SDW, which were submitted to sanitary and germination tests in a completely randomized experimental design, in a factorial arrangement $3 \times 3+1$ (exposure time $\times$ temperature + additional control). Data were subjected to analysis of variance, and the means were compared with the Scott-Knott test up to $5 \%$ of probability, with the aid of the statistical program SISVAR:. Immersing Zea mays seeds in hot water at 50,60 and $70{ }^{\circ} \mathrm{C}$ for 1,2 , and 3 minutes is efficient to prevent the increased incidence of Aspergillus sp., Penicillium sp., and Fusarium sp. The heat treatment at $60^{\circ} \mathrm{C}$ for 1 and 2 minutes of immersion reduces the incidence of fungal mycoflora without impairing the physiological quality of seeds.
\end{abstract}

KEYWORDS: alternative control; seed pathology; thermal stress.
RESUMO: O uso de sementes com bom potencial sanitário e fisiológico garante o estabelecimento da cultura, com estande de plântulas uniformes, vigorosas e livres de doenças, que consequentemente resultará em bons níveis de produtividade. Diante do exposto, objetivou-se avaliar a qualidade sanitária e fisiológica de sementes de milho roxo (Zea mays L.) submetidas à termoterapia, por meio de tratamento térmico com imersão em água destilada esterilizada (ADE), aquecida à temperatura de 50, 60 e 70 ${ }^{\circ} \mathrm{C}$ por 1,2 e 3 minutos. $\mathrm{O}$ controle $(0 \mathrm{~min})$ correspondeu apenas à imersão das sementes em ADE. As sementes foram submetidas aos testes de sanidade e germinaçáo em delineamento experimental inteiramente randomizado em esquema fatorial $3 \times 3+1$ (tempo de exposiçáo $\times$ temperatura + controle adicional). Os dados foram submetidos à análise de variância e as médias foram comparadas pelo teste de Scott-Knott até 5\% de probabilidade, com o auxílio do programa estatístico SISVAR ${ }^{\circledR}$. A imersão das sementes de Zea mays em água quente a 50,60 e $70{ }^{\circ} \mathrm{C}$ durante 1,2 e 3 minutos é eficiente para impedir o aumento da incidência de Aspergillus sp., Penicillium sp. e Fusarium sp. O tratamento térmico a $60{ }^{\circ} \mathrm{C}$ por 1 e 2 minutos de imersão reduz a incidência da micoflora fúngica, sem prejudicar a qualidade fisiológica das sementes.

PALAVRAS-CHAVE: controle alternativo; patologia de sementes; estresse térmico. 


\section{INTRODUCTION}

Due to its productive potential, chemical composition, and nutritive value, corn (Zea mays $\mathrm{L}$.) is one of the most important cereals grown in the world (MODESTO et al., 2014). However, greater productivity requires not only adequate cultivation methods, but also the use of high quality seeds, which is determined by a set of genetic, physical, physiological and sanitary attributes (ROSSI et al., 2017).

The sanitary quality of seeds can be compromised by fungi in all steps of the production process. These pathogens are responsible for the reduction in physiological quality, can be disseminated all over long distances through infected seeds, and are transmitted from the seed to the seedling (SANTOS et al., 2016). Eliminating or reducing these pathogens is being efficiently achieved through chemical treatments (DOMENE et al., 2016). Nonetheless, there has been growing interest worldwide for alternative seed treatment methods that cause less harm to the environment and human health, such as the use of vegetal extracts, essential oils, biological control and physical treatments (MEDEIROS et al., 2015; PEREIRA et al., 2015).

Physical treatment, such as thermotherapy, is an alternative method with considerable potential, especially to control pathogens adhered to the surface or contained in the interior of seeds (PEREIRA et al., 2015). Although efficient in the control of pathogens, the efficiency of this method is directly related to knowledge of the different degrees of sensitivity to thermal stress between the seed and the pathogen. Thus, the ideal period to expose seeds to heat treatment is when the pathogen can be controlled without causing harm to the physiological quality seeds (FRANÇOSO; BARBEDO, 2014).

Studies have demonstrated the effectiveness of thermotherapy for seeds. SCHNEIDER et al. (2015) found that the immersion of Jatropha curcas L seeds in water at 45, 50, and $55^{\circ} \mathrm{C}$ for 15 minutes was effective to control Penicillium sp., and Acremonium sp., without compromising the physiological quality of seeds. By immersing pumpkin (Cucurbita pepo) seeds at $60^{\circ} \mathrm{C}$ for 6 and 12 minutes, CUNHA et al. (2017) found a reduction in the incidence of Alternaria sp., Aspergillus sp., Cladosporium sp., Curvularia sp., Penicillium sp., Phoma sp., and Rhizopus sp., without affecting the physiological quality of seeds.

Therefore, the aim of this study was to evaluate the sanitary and physiological quality of purple corn (Zea mays L.) seeds submitted to thermotherapy.

\section{MATERIAL AND METHODS}

The experiment was conducted in the Phytopathology Laboratory of the Center for Agrarian Sciences of the Universidade Federal da Paraíba, Campus II, in the city of Areia, state of Paraíba, Brazil.

\section{Sanitation test}

Two hundred seeds were used per treatment, distributed in 20 replicates of 10 seeds each. The seeds were placed in tulle sacks, which were identified and placed randomly into a water bath at a predetermined temperature, and for a predetermined time.

The heat treatment method consisted of immersing the seeds in sterilized distilled water (SDW), heated to a temperature of 50,60 , and $70{ }^{\circ} \mathrm{C}$ for 1,2 , and 3 minutes. For the control (0 min), seeds were immersed in SDW at room temperature, placed into Petri dishes (diameter: $9 \mathrm{~cm}$ ), containing sterilized double-layer blotter test filter paper moistened with SDW. The dishes were incubated for 7 days at a temperature of $25 \pm 2{ }^{\circ} \mathrm{C}$ and a 12-hour photoperiod (BRASIL, 2009).

The detection and identification of fungi was performed with the aid of an optical microscope and stereoscope, as well as comparing results to those of specialized literature (SEIFERT et al., 2011). Data were expressed as the percentage of infected seeds.

\section{Germination test}

For the evaluation of physiological quality, 200 seeds were divided into 4 replicates of 50 seeds for each treatment, distributed on 2 sheets of germ-test paper, covered with a third sheet, and organized in a roll form. The paper had been previously sterilized and moistened with SDW at a proportion of $2.5 \%$ of its dry weight, placed in transparent plastic bags to avoid losing water through evaporation, and it was finally incubated in a biochemical oxygen demand (BOD) germinator, set at a temperature of $25^{\circ} \mathrm{C}$ and a 12 -hour photoperiod.

The evaluations were performed four and seven days after sowing, following the criteria established by BRASIL (2009). Germination was evaluated considering the number of normal seedlings on Day Four (first count), and Day Seven. The data were expressed in percentage values. The germination velocity index (GVI) was determined by a daily count of normal seedlings using the formula proposed by MAGUIRE (1962),

$$
\mathrm{GVI}=\frac{\mathrm{G}_{1}}{\mathrm{~N}_{1}}+\frac{\mathrm{G}_{2}}{\mathrm{~N}_{2}}+\ldots+\frac{\mathrm{G}_{\mathrm{n}}}{\mathrm{N}_{\mathrm{n}}}
$$

In which:

$G_{1}, G_{2}$, and $G_{n}$ correspond to the number of normal seedlings germinated each day;

and $\mathrm{N}_{1}, \mathrm{~N}_{2}$ and $\mathrm{N}_{\mathrm{n}}$ to the number of days from the sowing to the first and last counts.

The shoot length (SL), and root length (RL) were determined with the aid of a centimeter ruler, and the result was expressed in centimeters. The shoot dry matter (SDM) and rood dry matter (RDM) content were determined at the end of the evaluation by cutting the parts of the seedlings with the aid of a scalpel. The parts were then placed in Kraft paper sacks 
and dried in a thermoelectric oven at $65^{\circ} \mathrm{C}$, until reaching a constant weight $(72 \mathrm{~h})$ to determine dry mass. The samples were then weighed on an analytical scale with a precision of $0.001 \mathrm{~g}$ and the results were expressed in grams (CARVALHO; NAKAGAWA, 2012).

\section{Statistical analysis}

The experimental design was entirely randomized in a $3 \times 3+$ 1 factorial scheme (exposure time $\times$ temperature + additional control). The data were submitted to analysis of variance and means were compared using the Scott-Knott test with a 5\% probability. The analysis was performed with the aid of the SISVAR' statistical program.

\section{RESULTS AND DISCUSSION}

\section{Sanitary quality}

In the determination of sanitary quality of purple corn seeds (Zea mays L.), the fungi Aspergillus sp., Fusarium sp., Penicillium sp., Cladosporium sp., and Monilia sp. were found, but the low incidence of the latter two genera was not sufficient to reduce the quality of seeds. The detection of Fusarium sp., Penicillium sp., and Aspergillus sp. is in agreement with data described in previous studies, in which these fungi are described as the main microorganisms associated with corn kernels in Brazil (PINTO, 2001; 2005; RAMOS et al., 2010). A statistically significant difference $(\mathrm{p}<0.05)$ was found in the interaction between temperature and immersion time, regarding the percentage of occurrence of Penicillium sp., Fusarium sp., and Aspergillus sp. (Fig. 1), which agrees with data described by NOAL et al. (2014), and DOMENE et al. (2016), who also determined the occurrence of these fungi in corn seeds (Zea mays L.).

The maximum occurrence of Aspergillus sp., Penicillium sp., and Fusarium sp. was 20.5, 63, and 50.5\%, respectively, in the 0 -immersion time (Fig. 1). These rates are higher than those reported by DOMENE et al. (2016), who investigated the effect of essential oils on corn seeds, and found rates of 3.4\% for Aspergillus spp., $23.4 \%$ for Penicillium spp., and $19.8 \%$ for Fusarium sp. In contrast, NOAL et al. (2014) found higher rates (26\% for Aspergillus spp., 99\% for Penicillium spp., and $100 \%$ for Fusarium sp.) at different harvest points of a corn variety in the state of Rio Grande do Sul (Southern Brazil).

A reduction in the incidence of Aspergillus sp. was found in the seeds submitted to thermotherapy, independently of water temperature and immersion time (Fig. 1). However, the seeds treated with a temperature of $60^{\circ} \mathrm{C}$ caused the control of this fungus, with a statistically significant difference when compared to the control treatment $(\mathrm{p}<0.01)$ (Fig. 1). A similar result is reported by VIEIRA et al. (2011), who found reductions in the incidence of Aspergillus spp., Penicillium spp., Fusarium spp., and Cladosporium spp. in coffee seeds (Coffea arabica $\mathrm{L}$.), using a heat treatment. The authors also found the elimination of this pathogen $(0 \%)$ when the seeds were submitted to water at a temperature of $60^{\circ} \mathrm{C}$ for 15 minutes.

All treatments were effective at reducing the incidence of Fusarium sp. The temperatures of 50 and $60^{\circ} \mathrm{C}$ were the most effective, because they considerably reduced the incidence of this pathogen in comparison to the control treatment when seeds were immersed for 3 minutes, and 1 minute, respectively (Fig. 1). These findings are in agreement with data reported by VIEIRA et al. (2011), who describe the effective thermal control of the fungus Fusarium spp., with different combinations of temperature and time, but with a considerable reduction when seeds were immersed at $60^{\circ} \mathrm{C}$ for $77^{\prime} 30^{\prime \prime}$. TANAKA et al. (2003) found that $F$. subglutinans remained viable after thermotherapy, but that many fungi were either controlled or eradicated. COUTINHO et al. (2007) also found a significant reduction in the occurrence of Fusarium viticillioides in corn seeds submitted to immersion in water at $60^{\circ} \mathrm{C}$ for 5, 10, and $20 \mathrm{~min}$.

According to PINTO (2005) and RAMOS et al. (2010), the high incidence of Fusarium sp., and Stenocarpella sp. is directly related to the higher incidence of corn kernels. The authors add that other fungi are also found with a high frequency, such as Penicillium spp., and Aspergillus spp.; however, these pathogens cause more damage to stored grains.

The reduction in Penicillium sp. was similar to that found for Aspergillus sp., and Fusarium sp. The difference between treatments was significant $(\mathrm{p}<0.01)$, with a reduction close to $0 \%$ under the effect of $60^{\circ} \mathrm{C}$ after 2 minutes of immersion (Fig. 1). Unlike the results found, LAZAROTTO et al. (2013) report that the treatment of seeds from the tree Peltophorum dubium (Spreng. [Taub.]) with wet heat at $80^{\circ} \mathrm{C}$ for over 5 minutes favored the incidence of Penicillium sp., and Aspergillus spp. BRAGA et al. (2010), and VIEIRA et al. (2011) report similar results to those found in the present study for tomato and coffee seeds, respectively, describing a reduction in the incidence of Penicillium sp. when submitted to heat treatment. Therefore, heat treatment should be applied in such a way that it does not affect the seed vigor, which could accelerate its deterioration, and make it more susceptible to the action of seed-rotting microorganisms (LAZAROTTO et al., 2013).

According to MACHINSKI JUNIOR et al. (2001), the high incidence of Penicillium sp. in corn kernels is worrisome, since this pathogen produces a mycotoxin (ochratoxin) that is associated with cancer in humans and animals. Despite the lower incidence of Aspergillus sp. in purple corn seeds, this pathogen is also considered an important mycotoxin-producing (alphatoxin) agent. The incidence of this fungus immediately after harvest has also been reported in other studies (STEFANELLO et al., 2012), but varies according to the genotype and/or climate conditions (RAMOS et al., 2010). 
Although the greater prevalence of Penicillium sp. was related to asymptomatic kernels in the present study, PINTO (2001) states that this fungus is normally not associated with corn kernels immediately after harvest, but can be a cob-rotting agent. Moreover, due to the lack of evident signs, symptomatic kernels can be selected and transported to storage, where the fungus can cause severe damage.

\section{Physiological quality}

Based on the results of the first count and germination, no statistically significant differences $(p>0.05)$ were found between different temperatures, times, and temperature-time interactions, with rates from 47 to $50 \%$ for these variables. Therefore, none of the treatments rendered the germination of the seeds unviable. This finding is in agreement with data described by SCHNEIDER et al. (2015), who report no significant effect $(p>0.05)$ of the interaction between thermotherapy temperatures and storage periods on the germination of Jatropha curcas L. seeds, describing an increase in the percentage of germination throughout a 90 -day period, with a germination rate ranging from 66 to $68 \%$.

For the GVI, SL, RL, seedling length (SdL), SDM, root dry matter (RDM), and total dry weight (TDW), a significant interaction $(\mathrm{p}<0.01)$ was found between temperature and immersion time (Fig. 2).
The highest GVI values were obtained with seeds submitted to thermotherapy at 50 and $60^{\circ} \mathrm{C}$, which did not differ significantly from the control treatment (0 min.). In contrast, GVI values decreased significantly $(\mathrm{p}<0.01)$, with the increase in immersion time at $70{ }^{\circ} \mathrm{C}$, compared to other treatments (Fig. 2). MATHEUS; LOPES (2007) and SCHNEIDER et al. (2015) also found that the increase in exposure time of Schyzolobium parahyba, and Jatropha curcas seeds to heated water resulted in a reduction in the germination percentage and GVI, likely due to damage to the embryo, resulting from prolonged exposure to water at a very high temperature. Similar results were found in this study, as a lower GVI was found for seeds submitted to a higher immersion temperature.

A significant temperature-immersion time interaction ( $\mathrm{p}<0.01$ ) was found regarding SL (Fig. 2). Higher values were observed when seeds were submitted to thermotherapy at 50 and $70{ }^{\circ} \mathrm{C}$, with no statistically significant differences in comparison to the control treatment (0 immersion time). However, the immersion at $60{ }^{\circ} \mathrm{C}$ for 2 and 3 minutes led to a reduction in SL (Fig. 2). The maintenance of seed viability and vigor above the optimal temperature may be explained by repair mechanisms in membranes, mitochondria, proteins, and RNA, as well as the synthesis of thermal shock proteins and the action of antioxidants (MARCOS FILHO, 2015). According to TAIZ; ZEIGER (2013), the growth and development of seedlings are compromised by a reduction in enzyme activity, and/or
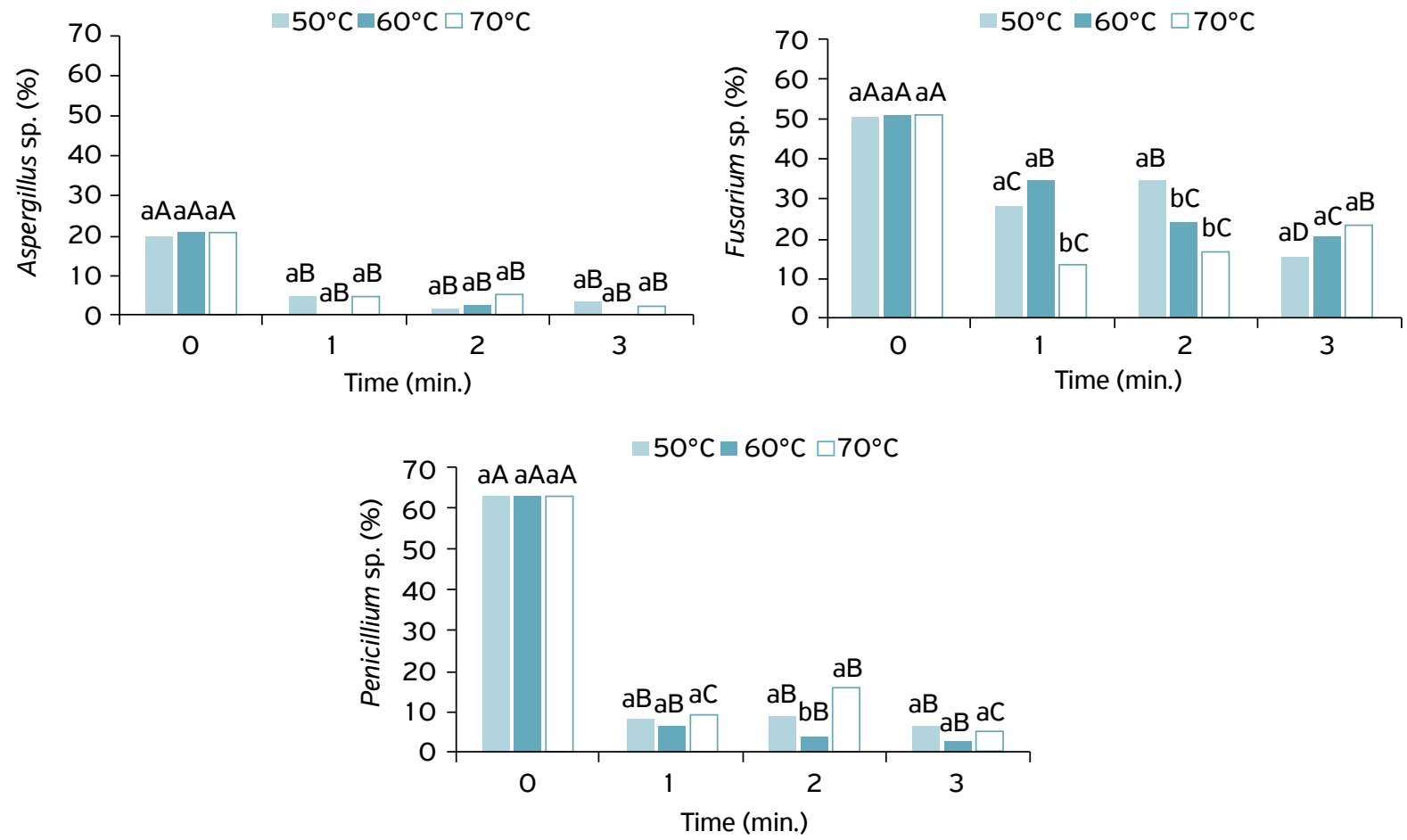

Figure 1. Occurrence of fungi associated with purple corn seeds (Zea mays L.), submitted to thermotherapy with hot water. Means followed by the same lowercase (comparison of temperatures) and uppercase (comparison of immersion times) letter do not differ significantly ( $p>0.05$, Scott-Knott test). 
diminished water absorption caused when seeds suffer a moderate degree of stress, such as thermal stress.

Similar behavior was found regarding RL and SdL (Fig. 2), with the highest values found in the thermotherapy treatments at 50 and $70{ }^{\circ} \mathrm{C}$, independently of the immersion time, and with no significant difference in comparison to the control treatment (0 immersion time). SdL results were similar to findings described by DOMENE et al. (2016), who evaluated the effect of treatment with essential oils applied to corn seeds, and found that most treatments did not have a negative effect on seedling development, like demonstrated by the lack of significant differences compared to the control treatment.

Thermotherapy at $60{ }^{\circ} \mathrm{C}$ for 2 and 3 minutes led to a slight reduction in root and $\mathrm{SdL}$, with a significant difference $(\mathrm{p}<0.01)$ in comparison to the control treatment $(0$ immersion time) (Fig. 2). From these results, one may infer that this
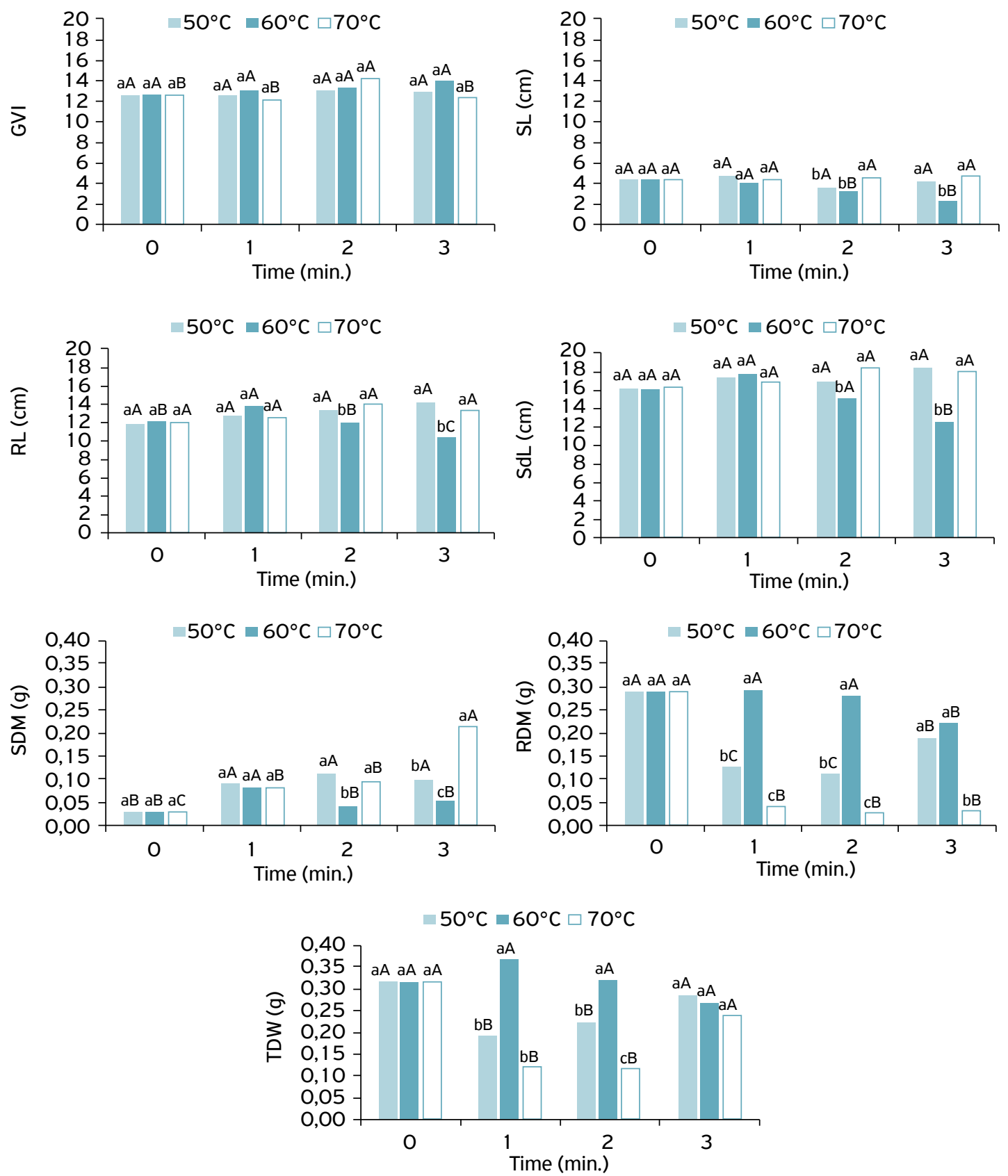

GVI: germination velocity index; SL: shoot length; RL: root length; SdL: seedling length; SDM: shoot dry matter; RDM: root dry matter; TDM: total dry matter.

Figure 2. Characterization of the physiological quality of purple corn seeds (Zea mays L.), submitted to thermotherapy with hot water based on the germination velocity index, shoot length, root length, seedling length, shoot dry matter, root dry matter and total dry matter. Means followed by the same lowercase (comparison of temperatures) and uppercase (comparison of immersion times) letter do not differ significantly ( $p>0.05$, Scott-Knott test). 
temperature and these immersion times cause more harm to the seeds than shorter immersion times, leading to harm to the seedlings. This is in agreement with data described by SANTOS et al. (2016), who found that thermotherapy led to a reduction in the height of soybean seedlings, especially with exposure times from 30 to 50 minutes to wet heat. However, dry heat can also cause physiological damage, like MENEZES et al. (2012) reported for rice seeds submitted to different dry temperatures.

All treatments led to a statistically significant increase in the SDM content $(\mathrm{p}<0.01)$ in comparison to the control (0 immersion time), especially the treatment at $70{ }^{\circ} \mathrm{C}$ for 3 minutes, with the accumulation of $0.20 \mathrm{~g}$ seedling $^{-1}$, surpassing that of other treatments (Fig. 2). By evaluating the physiological quality of Peltophorum dubium seeds submitted to wet heat at $80{ }^{\circ} \mathrm{C}$ for 5 minutes, LAZAROTTO et al. (2013) also found an increase in dry matter content, with a maximum of $0.21 \mathrm{~g}$ seedling $^{-1}$.

A significant temperature $\mathrm{x}$ immersion time interaction $(\mathrm{p}<0.01)$ was found for RDM. The best values occurred at $60{ }^{\circ} \mathrm{C}$, independently of immersion time, except when seeds were submitted to this temperature for 3 minutes, which led to a reduction in RDM content (Fig. 2). Thermotherapy at $70{ }^{\circ} \mathrm{C}$ considerably affected root development, with the lowest RDM values compared to all other treatments (Fig. 2). Probably, thermal stress altered the balance between the production of reactive oxygen species (ROS) and ROS elimination enzymes, partially reducing the metabolic activity needed to continue and stimulate normal root growth (RASHID et al., 2017).
Regarding TDW content (Fig. 2), thermotherapy at 50, 60 , and $70{ }^{\circ} \mathrm{C}$ for 3 minutes maintained significant values $(\mathrm{p}<0.01)$, with no difference in comparison to the control treatment ( 0 immersion time). The highest TDW was found with thermotherapy at $60^{\circ} \mathrm{C}$ for 1 minute (Fig. 2). Temperature is considered the most important factor to the velocity and percentage of seed germination, and the emergence of seedlings. Moreover, high temperatures can trigger the denaturation of proteins and enzymes responsible for maintaining the tolerance of seeds to heat (DUTRA et al., 2015). It is possible that the maintenance of the dry matter content in the treatments is related to seed vigor, because more vigorous seeds are more tolerant to a broader temperature range without compromising the germination process (SCHNEIDER et al., 2015). When evaluating the effect of temperature on soybean seeds (Glycine max), SANTOS et al. (2016) found a reduction in the height and dry weight of seedlings with the increase in exposure time to wet heat at $40{ }^{\circ} \mathrm{C}$.

\section{CONCLUSIONS}

The present findings show that the immersion of Zea mays in hot water at 50,60 and $70{ }^{\circ} \mathrm{C}$ for 1,2 , and 3 minutes is effective to prevent an increase in the incidence of Aspergillus sp., Penicillium sp., and Fusarium sp. Heat treatment at $60{ }^{\circ} \mathrm{C}$ for 1 and 2 minutes of immersion reduces the incidence of fungal microflora, without compromising the physiological quality of seeds.

| | | | | | | | | | | | | | | | | | | | | | | | | | | | | | | | | | | | | | | | | | | | | | | | | | | | | | | | | | | | | | | | | | | | | | | | | | | | | | | | | | | | | | | | | | | | | | | | | | | | | | | | | | | | | | | | | | | | | | | | | | | | | | | | | | | | | | | | | | | | | | | | | | | | | | | | | | | | | | | | | | | | | | | | | | | | | | | | | | | | | | | | | | | | | | | | | | | | | | | | | | | | | | | | | | | REFERENCES

BRAGA, M.P.; OLINDA, R.A.; HOMMA, S.K.; DIAS, C.T.S. Relações entre tratamento térmico, germinação, vigor e sanidade de sementes de tomate. Revista Brasileira de Sementes, Londrina, v.32, n. 1, p.101-1 10, 2010.http://dx.doi.org/10.1590/S0101-31222010000100012

BRASIL. Ministério da Agricultura, Pecuária e Abastecimento. Regras para análise de sementes. Brasília, DF: Secretaria de Defesa Agropecuária, MAPA/ACS, 2009. 398p.

CARVALHO, N. M.; NAKAGAWA, J. Sementes: ciência, tecnologia e produção. Jaboticabal, FUNEP, 2012. 590p.

COUTINHO, M.C.; SILVA-MANN, R.; VIEIRA, M.G.G.C.; MACHADO, C.F.; MACHADO, J.C. Qualidade sanitária e fisiológica de sementes de milho submetidas a termoterapia e condicionamento fisiológico. Fitopatologia Brasileira, Brasília, v.32, n.6, p.458-464, 2007. http://dx.doi.org/10.1590/SO100-41582007000600002
CUNHA, R.P.; CARVALHO, I.L.; OLSEN, D.; VIEIRA, J.F.; SOARES, V.N.; TUNES, L.M. Termoterapia no controle de patógenos associados às sementes de abóbora. Tecnologia $\odot$ Ciência Agropecuária, João Pessoa, v.11, n.2, p.53-57, 2017.

DOMENE, M.P.; GLORIA, E.M.; BIAGI, J.; BENEDETTI, B.C.; MARTINS, L. Efeito do tratamento com óleos essenciais sobre a qualidade fisiológica e sanitária das sementes de milho (Zea mays). Arquivos do Instituto Biológico, São Paulo, v.83, n.7, p.1-6, 2016. http:// dx.doi.org/10.1590/1808-1657000072014

DUTRA, S.M.F.; VON PINHO, E.V.R.; SANTOS, H.O.; LIMA, A.C.; VON PINHO, R.G.; CARVALHO, M.L.M. Genes related to high temperature tolerance during maize seed germination. Genetics and Molecular Research, Ribeirão Preto, v.14, n.4, p.18047-18058, 2015. http://dx.doi.org/10.4238/2015. December.22.31 
FRANÇOSO, C.F.; BARBEDO, C.J. Tratamentos osmóticos e térmicos para controle de fungos em sementes de grumixameira (Eugenia brasiliensis Lam.) e pitangueira (Eugenia uniflora L.). Hoehnea, São Paulo, v.4 1, n.4, p.541-552, 2014. http://dx.doi. org/10.1590/2236-8906-30/2013

LAZAROTTO, M.; MEZZOMO, R.; MACIEL, C.G.; BOVOLINI, M.P.; MUNIZ, M.F.B. Tratamento de sementes de canafístula via calor úmido. Revista de Ciências Agrárias, Viçosa, v.56, n.3, p.268-273, 2013. http://dx.doi.org/10.4322/ rca. 2013.038

MACHINSKI JUNIOR, M.; VALENTE SOARES, L.M.; SAWAZAKI, E.; BOLONHEZI, D.; CASTRO, J.L.; BORTOLLETO, N. Aflatoxins, ochratoxin $A$ and zearalenone in Brazilian corn cultivars. Journal of the Science of Food and Agriculture, Washington, v.81, n.10, p.1001-1007, 2001. https://doi.org/10.1002/ jsfa.882

MAGUIRE, J.D. Speed of germination: aid in selection and evaluation for seedling emergence and vigour. Crop Science, Madison, v.2, n.2, p.176-177, 1962. http://dx.doi.org/10.2135/ cropsci1962.0011183X000200020033x

MARCOS FILHO, J. Fisiologia de sementes de plantas cultivadas. 2. ed. Piracicaba: FEALQ, 2015.660p.

MATHEUS, M.T.; LOPES, J.C. Termoterapia em Sementes de Guapuruvú (Schyzolobium parahyba (Vell.) Blake). Revista Brasileira de Biociências, Porto Alegre, v.5, supl.2, p.330-332, 2007.

MEDEIROS, J.G.F.; NETO, A.C.A.; SILVA, E.C.; HUANG, M.F.N.; NASCIMENTO, L.C. Qualidade sanitária de sementes de Caesalpinia ferrea: incidência de fungos, controle e efeitos na qualidade fisiológica com o uso de extratos vegetais. Floresta, Curitiba, v.45, n.1, p.163-174, 2015. http://dx.doi.org/10.5380/ rf.v45i 1.34074

MENEZES, N.L.; PASQUALLI, L.L.; BARBIERI, A.P.P.; VIDAL, M.D.; CONCEIÇÃO, G.M. Temperaturas de secagem na integridade física, qualidade fisiológica e composição química de sementes de arroz. Pesquisa Agropecuária Tropical, Goiânia, v.42, n.4, p.430-436, 2012. http://dx.doi.org/10.1590/ S1983-40632012000400011

MODESTO, L.R.; LUSTRI, E.A.; SOARES, F.J.V.L.; SILVA, R.P.F.D.; FLUMINHAN-JUNIOR, A. Seleção recorrente fenotípica visando à obtenção de uma variedade sintética de milho (Zea mays L.). Colloquium Agrariae, São Paulo, v.10, n.2, p.20-31, 2014. 10.5747/ca.2014.v10.n2.a104

NOAL, G.; MUNIZ, M.F.B.; HENNING, L.M.M.; BARBIERI, M. Ponto de colheita de sementes de cultivares crioulas de milho no Rio Grande do Sul. Pesquisa Agropecuária Pernambucana, Recife, v.19, n.2, p.79-84, 2014. https://doi.org/10.12661/ pap.2014.012

PEREIRA, R.B.; SILVA, P.P.; NASCIMENTO, W.M.; PINHEIRO, J.B. Tratamento de sementes de hortaliças. Brasília: Embrapa Hortaliças. 2015. 16p. (Embrapa Hortaliças. Circular Técnica, 140).
PINTO, N.F.J.A. Qualidade sanitária de grãos de milho. Sete Lagoas: Embrapa Milho e Sorgo. 2001. 4p. (Embrapa Milho e Sorgo. Comunicado Técnico, 30).

PINTO, N.F.J.A. Grãos ardidos em milho. Sete Lagoas: Embrapa Milho e Sorgo. 2005. 5p. (Embrapa Milho e Sorgo. Circular Técnica, 66).

RAMOS, A.T.M.; MORAES, M.H.D.D.; CARVALHO, R.V.D.; CAMARGO, L.E.A. Levantamento da micoflora presente em grãos ardidos e sementes de milho. Summa Phytopathologica, Botucatu, v.36, n.3, p.257-259, 2010. http://dx.doi.org/10.1590/ so $100-54052010000300015$

RASHID, M.; HAMPTON, J.G.; ROLSTON, M.P.; KHAN, K.M.; SAVILLE, D.J. Heat stress during seed development affects forage brassica (Brassica napus L.) seed quality. Journal of Agronomy and Crop Science, Berlin, v.204, n.2, p.147-154, 2017. https://doi. org/10.1111/jac. 12251

ROSSI, R.F.; CAVARIANI, C.; FRANÇA-NETO, J.B. Vigor de sementes, população de plantas e desempenho agronômico de soja. Revista de Ciências Agrarias, Viçosa, v.60, n.3, p.215-222, 2017. http:// dx.doi.org/10.4322/rca.2239

SANTOS, L.A.; FARIA, C.M.D.R.; MAREK, J.; DUHATSCHEK, E.; MARTINICHEN, D. Radiotherapy and thermotherapy as Soybean seed treatments. Revista Brasileira de Tecnologia Aplicada nas Ciências Agrárias, Guarapuava, v.9, n.2, p.37-44, 2016. https:// doi.org/10.5935/10.5935/PAeT.V9.N2.04

SCHNEIDER, C.F.; GUSATTO, F.C.; MALAVASI, M.M.; STANGARLIN, J.R.; MALAVASI, U.C. Termoterapia na qualidade fisiológica e sanitária de sementes armazenadas de pinhão-manso. Semina: Ciências Agrárias, Londrina, v.36, n.1, p.47-56, 2015. https:// doi.org/10.5433/1679-0359.2015v36n $1 \mathrm{p} 47$

SEIFERT, K.; MORGAN-JONES, G.; GAMS, W.; KENDRICK, B. The genera of Hyphomycetes. 1. ed. Utrecht: CBS-KNAW Fungal Biodiversity Centre, $2011.866 p$.

STEFANELLO, J.; BACHI, L.M.A.; GAVASSONI, W.L., HIRATA, L.M.; PONTIM, B.C.A. Incidência de fungos em grãos de milho em função de diferentes épocas de aplicação foliar de fungicida. Pesquisa Agropecuária Tropical, Goiânia, v.42, n.4, p.476-481, 2012. http://dx.doi.org/10.1590/S1983-40632012000400014

TAIZ, L.; ZEIGER, E. Fisiologia vegetal. 5. ed. Porto Alegre: Artmed, 2013. $918 p$.

TANAKA, M.A.S.; ITO, M.F.; BRAGA, C.A.S.; ARMOND, G. Tratamento térmico solar da água para controle de fitopatógenos. Fitopatologia Brasileira, Brasília, v.28, n.4, p.386-393, 2003. http://dx.doi. org/10.1590/SO100-41582003000400007

VIEIRA, J.F.; ABREU, M.S.; MAIA, F.G.M.; OGOSHI, C.; PIERRE, R.O.; CARVALHO, E.A.; SILVA, B.M. Tratamento térmico de sementes no manejo da mancha manteigosa causada por Colletotrichum Gloeosporioides em cafeeiro Coffea Arabica L. Acta Ambiental Catarinense, Chapecó, v.8, n.1/2, p.27-38, 2011 . http://dx.doi. org/10.24021/raac.v8i1/2.1927 